\title{
LENGTH-WEIGHT RELATIONSHIP AND CONDITION FACTOR OF THE ENDANGERED AND ENDEMIC PRESPA TROUT (SALMO PERISTERICUS KARAMAN, 1938) FROM LEVA RIVER, KRANSKA RIVER AND BRAJČINSKA RIVER
}

\author{
Vasil Kostov $^{1}$, Irina Manevska ${ }^{1}$, Julijana Arsovska ${ }^{2}$, Silvana Manasievska Simić ${ }^{3}$ \\ ${ }^{1}$ Fishery Department, Institute of Animal Science, Ss. Cyril and Methodius University in Skopje, \\ Blvd. Ilinden 92a, Skopje, Republic of North Macedonia \\ ${ }^{2}$ Institute of Biology, Faculty of Natural Sciences and Mathematics, \\ Ss. Cyril and Methodius University in Skopje, Arhimedova 5, Skopje, Republic of North Macedonia \\ ${ }^{3}$ Faculty of Agricultural Sciences and Food, Ss. Cyril and Methodius University in Skopje, \\ Blvd. Aleksandar Makedonski bb, 1000 Skopje, Republic of North Macedonia \\ inst.stoc.kostov@gmail.com
}

\begin{abstract}
A b s t r a c t: The Prespa trout is a known mountain resident to four tributaries of Prespa Lake in a small area of the Prespa region. Facing threat of extinction, the endemic Prespa trout was categorized as an endangered species. The goal of this paper is to provide information on the condition factor and the L-W relationship with non-lethal research techniques. Electrofishing was conducted on a total of 27 sampling points on Leva, Kranska and Brajčinska rivers. The results showed that Prespa trout have long and slender bodies with low weight value. The condition factor of Prespa trout is poor to extremely poor ranging from 0.7 to 1 . L-W as a relationship between weight and length, is used for the growth pattern estimation and condition index, in order to enrich conservation studies and aid management decision makers at national level. L-W relationship and condition factor are closely related and useful for evaluation of fish populations.
\end{abstract}

Key words: Prespa trout; endangered; assessment; length-weight relationship; Fulton's coefficient

\section{ДОЛЖИНСКО-ТЕЖИНСКИ ОДНОС И ФАКТОР НА КОНДИЦИЈА НА ЕНДЕМСКАТА И ЗАГРОЗЕНА ПРЕСПАНСКА ПАСТРМКА (SALMO PERISTERICUS KARAMAN, 1938) ОД ЛЕВА РЕКА, КРАНСКА РЕКА И БРАЈЧИНСКА РЕКА}

\begin{abstract}
А п с т р а к т: Преспанската пастрмка ги населува четирите планински притоки на Преспанското Езеро, мала област во рамките на преспанскиот регион. Соочена со закана од исчезнување, ендемиската преспанска пастрмка е категоризирана како загрозен вид. Целта на овој труд е да обезбеди податоци за факторот на кондиција $(\mathrm{F})$ и должинско-тежинскиот однос (однос $\mathrm{L}-\mathrm{W})$ преку изведување на нелетални истражувачки техники. Електрориболовот беше спроведен на вкупно 27 профили за земање примероци на реките Лева, Кранска и Брајчинска. Резултатите покажаа дека преспанската пастрмка се одликува со долго и витко тело со мала маса. Факторот на кондиција на преспанската пастрмка се движи во границите од „лош“ до „екстремно лош“, со вредности од 0,7 до 1 . Односот L-W и факторот на кондиција се тесно поврзани и се корисни за евалуација на популациите риби. Тие се користат за процена на моделот на раст и индексот на кондиција, со цел да се збогатат студиите за зачувување на преспанската пастрмка, како и да им се олесни носењето одлуки на носителите на управување на национално ниво.
\end{abstract}

Клучни зборови: преспанска пастрмка; загрозен вид; процена; тежинско-должински однос;, Фултонов коефициент

\section{INTRODUCTION}

Prespa trout, Salmo peristericus Karaman, 1938 (verbatim name Salmo macedonicus perister$i c u s$ ) is endemic fish species inhabiting four tributaries of Makro Prespa Lake in the Prespa region:
Leva River (tributary of Golema River), Brajčinska River, Kranska River and Agios Germanos River [1]. On the IUCN Red List, the Prespa trout was classified as an endangered species facing a very high risk of extinction in the wild [2]. The assessment was based on long-term studies of the Prespa 
trout's population, mainly in Agios Germanos River $[1,3]$. The first Species Action Plan with proposed conservation measurements was prepared in order to ensure a longterm conservation of the Prespa trout $[1,3]$. Populations of Prespa trout in Leva, Kranska and Brajčinska rivers were studied much less with exception of distribution studies $[4,5,6]$ and genetic studies [7]. Prespa trout is known for its small size, not exceeding $35 \mathrm{~cm}[1,4]$. Salmo peristericus is mainly an understudied fish species with not much known about its biology or ecology in these rivers. Population studies are required as well as reassessment of the conservation status. Information about the population distribution and trend, density and abundance, as well as biology, ecology of Prespa trout, are crucial for suitable species management and establishing a long-term protection and recovery of the endemic and endangered Prespa trout population.

Endemic fish species are sensitive to human impact, and therefore nonlethal techniques are more suitable for their investigation. L-W relationship and Fulton's condition factor (FCF) are an important tools for application in fishery science, biology and ecology and conservation studies that can help managers and conservationists make decisions [811]. $\mathrm{L}-\mathrm{W}$ relationship is used to provide the average fish weight of a certain length, while Fulton's $\mathrm{C}$ in determining the condition of the population. Weight parameters ( $a$ and $b$ ) are useful in several directions: estimating the weight and length of individual fish, calculating fish population indices, comparing the life cycle of fish and morphology of populations of different parts of the catchments and watersheds $[12,13,14]$.

The goal of this paper is to provide information on the L-W relationship parameters and the condition of the Prespa trout's population, assessed with nonlethal metrics in order to aid local management and conservation practices. The aim of this research is a part of a more comprehensive assessment of the conservation status of the Prespa trout populations in the Brajčinska, Kranska and Leva rivers, and their tributaries including the Pelister National Park in the Republic of North Macedonia.

\section{MATERIAL AND METHODS}

\section{Research area and data collection}

The sampling of Prespa trout was conducted during the late autumn season (November to December) in tributaries of Makro Prespa Lake (Braj- činska, Kranska and Leva rivers with their tributaries) on the territory of North Macedonia (Figure 1). The selection of the sampling points (27 total) was mainly based on the survey by [1]. Research area characteristics (GPS, description, altitude) and measured physicochemical properties (water temperature in ${ }^{\circ} \mathrm{C}$, dissolved oxygen in $\mathrm{ppm}, \mathrm{pH}$, salinity in $\mathrm{ppm}$, conductivity in $\mu \mathrm{S} / \mathrm{cm}$ ) of the sampling points are given in Table 1 .

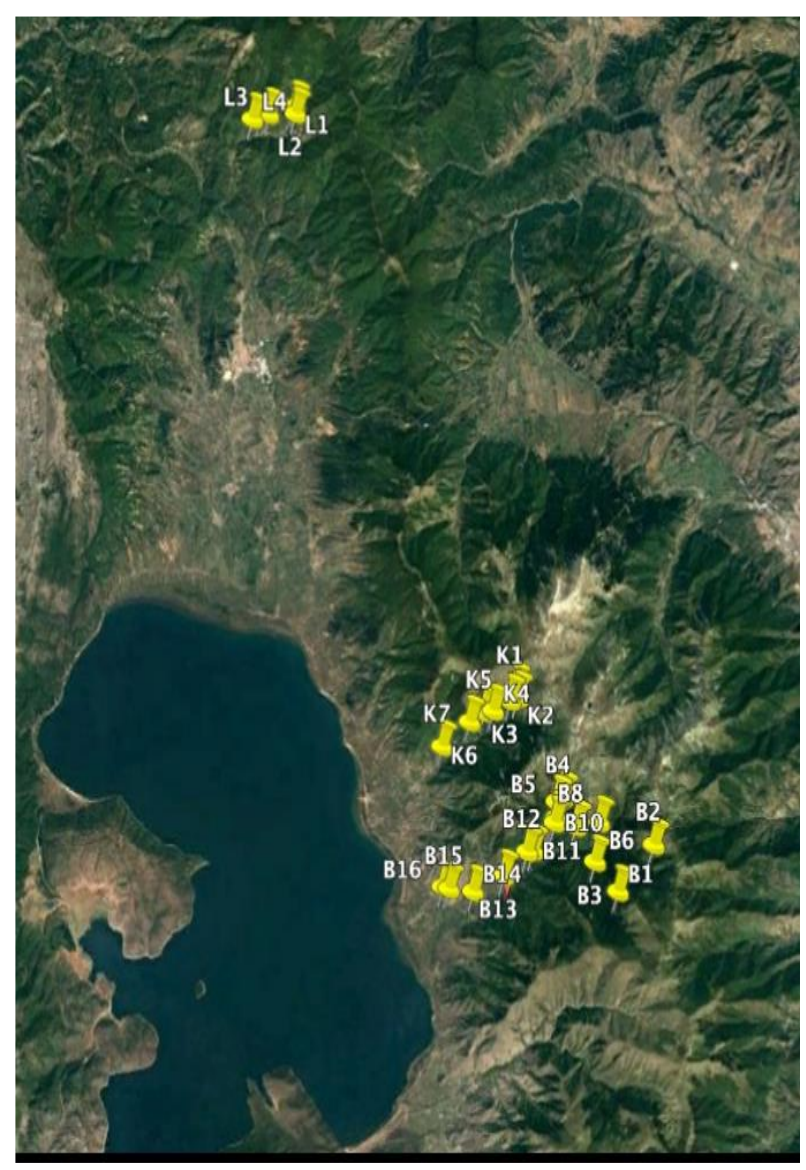

Fig. 1. Sampling points of the study at the tributaries of Makro Prespa Lake: Leva River, Kranska River and Brajčinska River (north to south) (for abbreviations see Table 1)

Electrofishing was conducted according to standard methodology (CEN Directive, 2003) with electric generators Samus 1000 and Samus 725 G. The body mass was obtained for every specimen to the nearest $0.1 \mathrm{~g}$. Basic morphometric measurements were taken (total length, fork length, body length). The sex was determined according to the fish sexual dimorphism. A total of 413 specimens were examined (Leva River $n=8$; Kranska River $n=178$ and Brajčinska River, $n=227$ ) and returned alive at the same location. Sampling points K7 and L1 showed absence of Prespa trout specimens. 
Table 1

Characteristics and physicochemical properties of the sampling points (SP) of Brajčinska River and tributaries (B1-B16), Kranska River and tributaries (K1-K7) and Leva River and tributaries (L1-L4)

\begin{tabular}{|c|c|c|c|c|c|c|c|c|c|}
\hline \multirow{2}{*}{$\begin{array}{l}\text { SP } \\
\text { mark } \\
\text { B1 }\end{array}$} & \multirow{2}{*}{$\frac{\text { River }}{\text { Ržanska River }}$} & \multirow{2}{*}{$\begin{array}{l}\text { Descrpition of sampling point } \\
\text { Sampling point at the highest altitude }\end{array}$} & \multicolumn{2}{|c|}{ GPS coordinateAltitude } & \multirow{2}{*}{$\frac{\left({ }^{\circ} \mathrm{C}\right)}{3.4}$} & \multirow{2}{*}{$\begin{array}{c}\mathrm{pH} \\
8\end{array}$} & \multirow{2}{*}{$\begin{array}{c}\text { DO ppm } \\
12.1\end{array}$} & \multicolumn{2}{|c|}{ Conductivity Salinity } \\
\hline & & & $\begin{array}{l}40.8951556 \\
21.2169734\end{array}$ & 1571 & & & & 36.8 & 16.4 \\
\hline$B 2$ & Brajčinska River & Sampling point at the highest altitude, Rupa area & $\begin{array}{l}40.911569 \\
21.2366257\end{array}$ & 1518 & 5.4 & 7.5 & 13.5 & 35.8 & 16.6 \\
\hline B3 & Ržanska River & Upstream and downstream of the concrete bridge & $\begin{array}{l}40.9056922 \\
21.2046308\end{array}$ & 1381 & 5.2 & 8.2 & 12.3 & 51.2 & 23.7 \\
\hline$B 4$ & Drmišar & $\begin{array}{l}\text { Upstream, junction of Brajčinska River with } \\
\text { Marušica }\end{array}$ & $\begin{array}{l}40.9287137 \\
21.1870883\end{array}$ & 1300 & 5.6 & 7.8 & 13.4 & 112 & 52 \\
\hline B5 & Marušica, Brajčinska & $\begin{array}{l}500 \text { meters upstream, the junction with Drmišar } \\
\text { river }\end{array}$ & $\begin{array}{l}40.9260916 \\
21.1835457\end{array}$ & 1286 & 6.1 & 7.9 & 12.4 & 77.3 & 36.3 \\
\hline B6 & Brajčinska River & Golem Dol, between SHPP and water intake & $\begin{array}{l}40.919247 \\
21.2062476\end{array}$ & 1228 & 3.8 & 8 & 12.9 & 172.6 & 78 \\
\hline$B 7$ & Baltanska River & Tributary of Brajčinska River & $\begin{array}{l}40.8981639 \\
21.1754088\end{array}$ & 1223 & 7.7 & 8.1 & 12.1 & 70.3 & 32.8 \\
\hline$B 8$ & Brajčinska River & Downstream, the water intake for SHPP PCC & $\begin{array}{l}40.9181438 \\
21.1943514\end{array}$ & 1202 & 5.2 & 7.8 & 12.6 & 66.2 & 30.1 \\
\hline$B 9$ & Stanišar & Upstream, the water intake for SHPP & $\begin{array}{l}40.9199579 \\
21.1824587\end{array}$ & 1194 & 5.3 & 7.8 & 13.4 & 70.3 & 31.1 \\
\hline$B 10$ & Stanišar & Downstream, the water intake for SHPP & $\begin{array}{l}40.9180173 \\
21.181943\end{array}$ & 1170 & 5.2 & 7.8 & 12.1 & 73.7 & 33.2 \\
\hline$B 11$ & Brajčinska River & Saint Ilija & $\begin{array}{l}40.9120561 \\
21.1789965\end{array}$ & 1111 & / & / & l & l & l \\
\hline B12 & Brajčinska River & $\begin{array}{l}300 \text { m downstream from the PCC SHPP, upstream } \\
\text { to Brajčino village }\end{array}$ & $\begin{array}{l}40.909132 \\
21.1668358\end{array}$ & 1040 & 8.3 & 7.6 & 10.3 & 66.8 & 57.5 \\
\hline$B 13$ & Brajčinska River & Between Brajčino and Ljubojno villages & $\begin{array}{c}40.8992765 \\
21.150944\end{array}$ & 945 & 8.1 & 7.6 & 10.8 & 71.1 & 32.4 \\
\hline B14 & Brajčinska River & In to the Brajčino village, under the wooden bridge & $\begin{array}{l}40.8958916 \\
21.1371943\end{array}$ & 908 & 5.7 & 8 & 12.2 & 122.5 & 56.4 \\
\hline Б15 & Brajčinska River & Upstream of the cascade & $\begin{array}{l}40.8968549 \\
21.1215941\end{array}$ & 871 & 6.5 & 7.8 & 12.6 & 125.7 & 58.6 \\
\hline Б16 & Brajčinska River & Downstream of the cascade & $\begin{array}{c}40.8969053 \\
21.120313\end{array}$ & 859 & 6.6 & 7.9 & 12.7 & 125.7 & 58.6 \\
\hline K1 & Srbina River & Upstream, junction of Kranska with Marušica rivers & $\begin{array}{l}40.9640508 \\
21.1592977\end{array}$ & 1420 & 6.1 & 7.4 & 11.3 & 85.2 & 4.6 \\
\hline$K 2$ & Marušica Kranska & Upstream junction with river of Srbina & $\begin{array}{l}40.9630681 \\
21.1616222\end{array}$ & 1410 & 5.4 & 7.5 & 11.1 & 27.6 & 12.5 \\
\hline$K 3$ & Kranska River & The first SP, downstream the forming & $\begin{array}{l}40.961847, \\
21.1555918\end{array}$ & 1341 & 6.6 & 8 & 10.1 & 82.2 & 38.8 \\
\hline K4 & Kranska River & Upstream of the water intake for SHPP "A" & $\begin{array}{c}40.9576009 \\
21.146132\end{array}$ & 1243 & 5,7 & 7.8 & 12.5 & 37.8 & 17.6 \\
\hline K5 & Recište & Upstream, inflow in Kranska River & $\begin{array}{c}40.9571672 \\
21.1420453\end{array}$ & 1225 & 7.1 & 7.7 & 11.7 & 111.1 & 50.5 \\
\hline K6 & Kranska River & Between of the water intake and SHPP & $\begin{array}{c}40.9547416 \\
21.1355744\end{array}$ & 1171 & 6.7 & 7.4 & 12.3 & 48.4 & 22.4 \\
\hline K7 & Kranska River & In to the Arvati village & $\begin{array}{c}40.9461383 \\
21.1198977\end{array}$ & 1034 & 8.1 & I & 10.5 & l & l \\
\hline L1 & Biglička River & $200 \mathrm{~m}$ upstream of the inflow in Leva River & $\begin{array}{l}41.1666794 \\
21.0368637\end{array}$ & 1058 & 5.4 & 7.6 & 10.5 & 88.7 & 40.6 \\
\hline$L 2$ & Leva River & The highest sampling point & $\begin{array}{l}41.1736788 \\
21.0388894\end{array}$ & 1054 & 6.1 & 7.6 & 10.3 & 17.3 & 50.7 \\
\hline$L 3$ & Leva River & Middle sampling point & $\begin{array}{l}41.167068 \\
21.0368365\end{array}$ & 1035 & 6.7 & 7.9 & 10.9 & 120.3 & 55.6 \\
\hline$L 4$ & Leva River & Upstream of Leva River & $\begin{array}{l}41.1661969 \\
21.0294434\end{array}$ & 1014 & 5.3 & 8 & 10.6 & 109.8 & 49.8 \\
\hline
\end{tabular}




\section{Length-weight relationship ( $L$-W relationship)}

Because the fish length can be measured very precisely, allowing rapid sorting of individuals into length classes as an effective and useful mathematical tool, suitable for most analyzing methods used to estimate fish condition L-W relationship was determined for male and female specimens of Brajčinska and Kranska rivers only, due to the low number of caught specimens in Leva River. The following formula is used for the length-weight relationship determination by fitting the data to a potential relationship based on the exponential equation [11]:

$$
W=a L^{b},
$$

where $W$ is the total weight (expressed in $\mathrm{g}$ ), $\mathrm{L}$ is the total length (expressed in $\mathrm{cm}$ ), $a$ is a coefficient related to body form and $b$ is an exponent. The value $b$ was calculated in an attempt to establish if the Prespa trout growth is allometric or isometric. The growth is isometric if the value of $b$ is 3.0. The growth is allometric if the fish grows faster and increases in length $(b<3.0)$, or increases weight and grows more slowly $(b>3.0)[15,16]$.

The parameters $a$ and $b$ of the exponential curve were estimated by linear regression analysis over log-transformed data expressed as:

$$
\log W=\log a+b \log L .
$$

For the parameters in the equation the linear relationship between $\log$ a $(\log$ arithmic value for $a$ ) and $\mathrm{b}$ was used [17]. The values of the constant $a$ and $b$ of the linear regression were determined according to $[18,19]$.

\section{Fulton's condition factor ( $F C F$ )}

Considering the fish wellbeing condition, there are three basic variants of condition factor estimation: Fulton's condition factor [20]. Relative

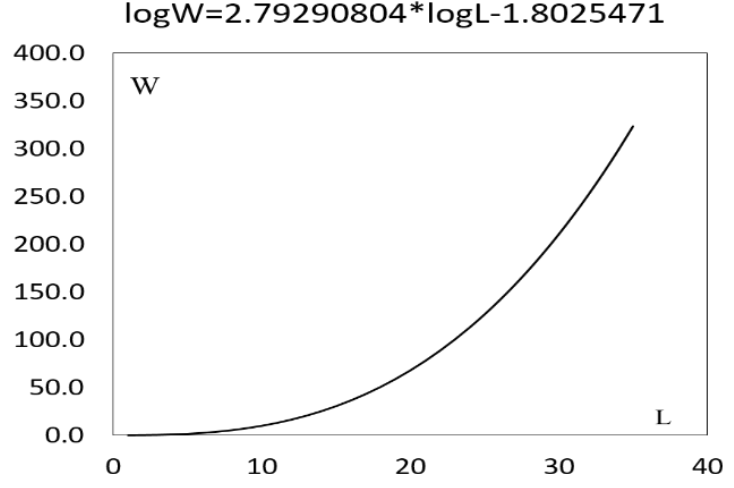

condition factor can be used as a tool for estimation and distinguishing the influences on condition of length and other factors [11] and relative weight factor, applicable for estimating fish body composition, as a measure of fish health and abundance assessment. Fulton's condition factor was calculated by using the formula:

$$
K=\left(W / L^{3}\right) \times 100,
$$

where $K=$ Fulton's condition factor, $W=$ weight of fish in grams, $L=$ total length in millimeters, $100=$ factor to bring the value near to unity. For salmons, $K$ values usually fall in the range from 0.8 to 2.0 [21].

\section{RESULTS AND DISCUSSION}

Salmo peristericus was sampled from relatively cold mountain watercourses with average $5.87^{\circ} \mathrm{C}$ for Leva and Brajčinska rivers and $6.7^{\circ} \mathrm{C}$ for Kranska River (Table 1). The concentration of dissolved oxygen in water is extremely high with mean values of $12.36 \mathrm{ppm}, 11.35 \mathrm{ppm}$ and $10.5 \mathrm{ppm}$ for Brajčinska, Kranska and Leva rivers, respectively. Low alkaline values were measured with mean of 7.9 at Brajčinska, 7.6 at Kranska and 7.8 at Leva rivers. The conductivity and salinity also have low values in all three rivers (Table 1).

The L-W relationship for the Prespa trout from Brajčinska and Kranska rivers is presented on Figures 2-4. Power function is describing the regression between the fish length and weight. The coefficient $b$ from the equation for female specimens from Kranska River is below 3, while for male specimens is above 3 (Figure 3). The coefficient $b$ for both male and female specimens from Brajčinska River is below 3 (Figure 2).

\section{$\log W=2.8968292 * \log L-1.9025717$}

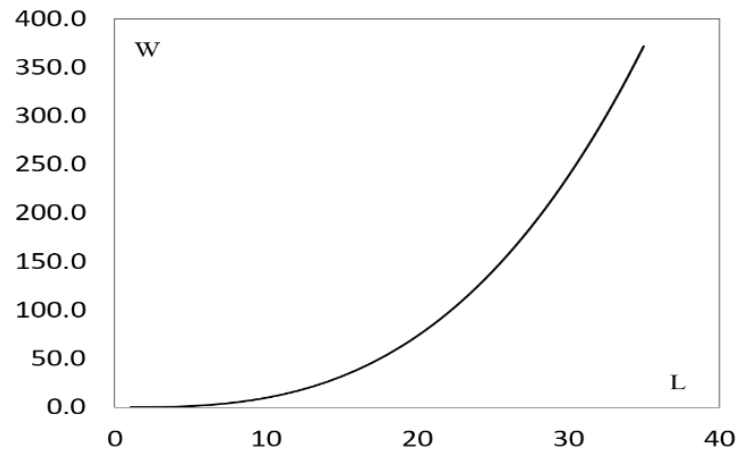

Fig. 2. Length-weight relationship for female (left) and male (right) specimens of Salmo peristericus from Brajčinska River 

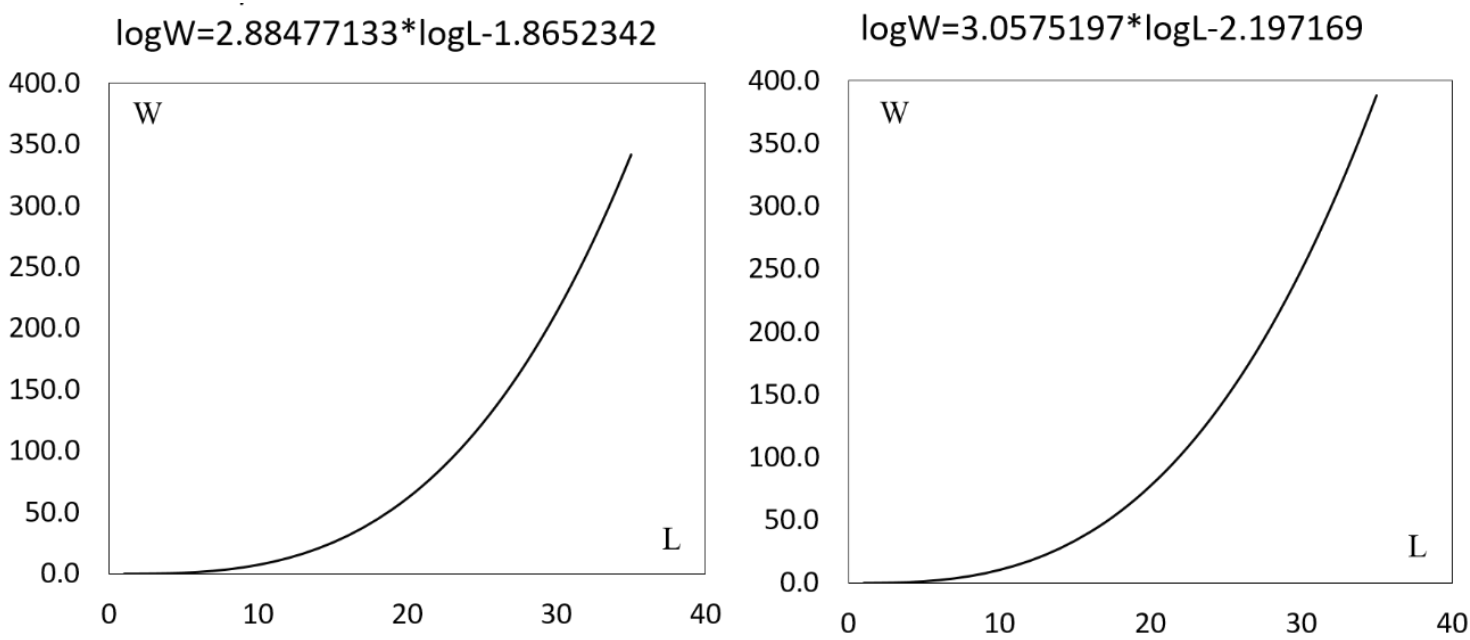

Fig. 3. Length-weight relationship in female (left) and male (right) population of Salmo peristericus from Kranska River.

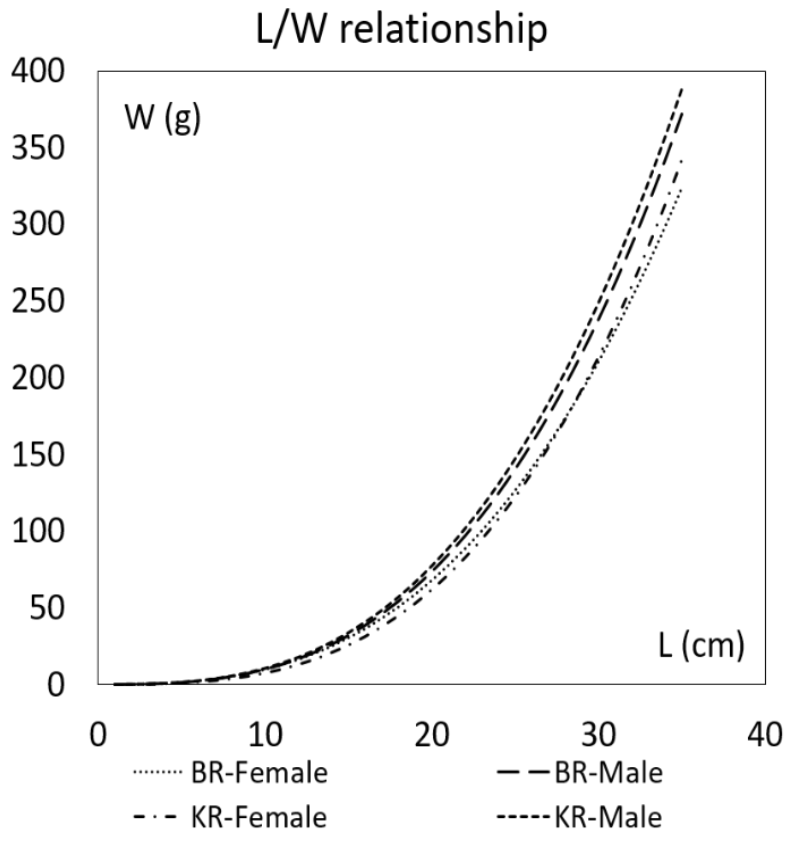

Fig. 4. Length-weight relationship in male and female population of Salmo peristericus from Brajčinska (BR) and Kranska River (KR)
The average condition factor (Fulton's condition factor) for Salmo peristericus in Brajčinska, Kranska and Leva rivers is $0.9 \pm 0.07$ (Table 2). The condition factor in specimens from Brajčinska River ranged from 0.7 to 1 . In Kranska River Fulton's K ranged from 0.9 to 1 , while in Leva River it ranged from 0.8 to 0.9. Males and juveniles in all three rivers have average condition factors of $0.93 \pm 0.08$ and $0.94 \pm 0.09$, respectively. On the other hand, the condition factor for females from all three rivers, on average is, $0.86 \pm 0.09$.

The condition factor for male, female and juvenile specimens of Salmo peristericus at every sample point is presented in Table 3. Leva River showed absence of juvenile specimens (Table 3). Mean values of condition factor show that all specimens of Salmo peristericus at B9 to B11 have the lowest condition factor, while at B5 and B12 have the highest condition factor (Figure 5). Specimens of Salmo peristericus in Kranska River have mean values of Fulton's condition factor (FCF) that do not fall under 0.9 (Figure 5).

Table 2

Mean Fulton's condition factor for Salmo peristericus in Brajčinska, Kranska and Leva rivers

\begin{tabular}{|c|c|c|c|c|c|c|c|c|c|c|c|}
\hline \multirow{2}{*}{ River } & \multicolumn{3}{|c|}{ Male } & \multicolumn{3}{|c|}{ Female } & \multicolumn{3}{|c|}{ Juvenile } & \multicolumn{2}{|c|}{ Total } \\
\hline & Mean & SD & Min - Max & Mean & SD & Min - Max & Mean & SD & Min - Max & Mean & SD \\
\hline Brajčinska & 0.89 & 0.08 & $0.8-1$ & 0.87 & 0.09 & $0.7-1$ & 0.94 & 0.09 & $0.8-1$ & 0.9 & 0.08 \\
\hline Kranska & 0.97 & 0.05 & $0.9-1$ & 0.92 & 0.08 & $0.9-1$ & 0.94 & 0.05 & $0.9-1$ & 0.9 & 0.04 \\
\hline Leva & 0.93 & 0.06 & $0.9-1$ & 0.8 & 0 & $0.8-0.8$ & - & - & - & 0.9 & 0.08 \\
\hline Total & 0.93 & 0.08 & & 0.86 & 0.9 & & 0.94 & 0.08 & & 0.9 & 0.07 \\
\hline
\end{tabular}


Table 3

Condition coefficient's results (Fulton's condition coefficient) for male, female and juvenile specimens of Salmo peristericus at all sampling points (see Methods and Material for abbreviations)

\begin{tabular}{cccc}
\hline \hline SP & Male & Female & Juvenile \\
\hline B1 & - & 0.9 & - \\
B2 & 0.9 & 1 & 0.8 \\
B3 & 0.9 & 0.8 & 0.9 \\
B4 & 0.9 & 0.8 & 0.9 \\
B5 & - & 1 & 1.1 \\
B6 & 0.8 & 0.8 & 0.9 \\
B7 & 0.8 & 0.7 & 1 \\
B8 & 0.9 & - & 1 \\
B9 & 0.8 & 0.8 & - \\
B10 & 0.8 & - & - \\
B11 & 0.8 & 0.8 & 0.8 \\
B12 & 1 & 1 & 1 \\
B13 & 0.9 & 0.9 & 1 \\
B14 & 1 & 0.9 & 0.9 \\
B15 & 1 & 0.9 & 1 \\
B16 & 1 & - & 0.9 \\
K1 & 1 & 1 & 0.9 \\
K2 & 0.9 & 0.9 & 0.9 \\
K3 & 1 & 0.9 & - \\
K4 & 1 & 0.8 & 0.9 \\
K5 & 0.9 & 0.9 & 1 \\
K6 & 1 & 1 & 1 \\
L1 & - & - & - \\
L2 & 0.9 & 0.8 & - \\
L3 & 0.9 & - & - \\
L4 & 1 & - & - \\
\hline \hline & & & \\
\hline
\end{tabular}

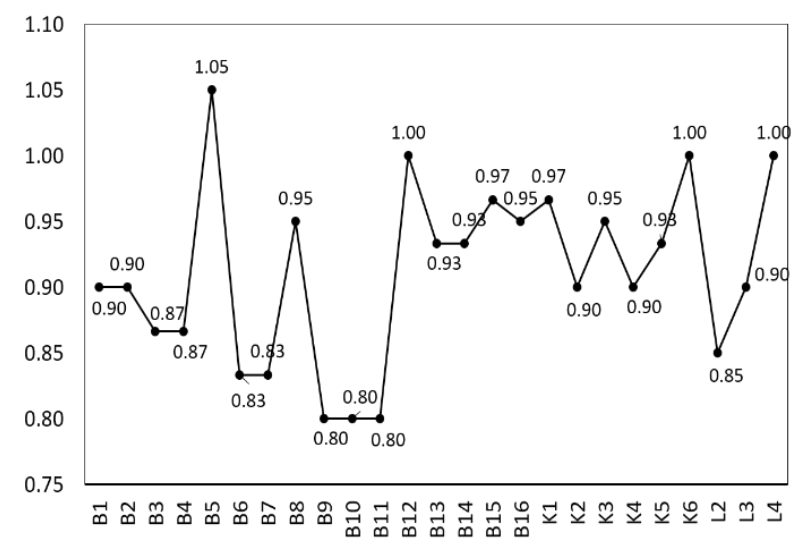

Fig. 5. Mean Fulton's coefficient of Prespa trout in all 27 sampling points of Brajčinska, Kranska and Leva rivers (see Material and Methods for abbreviations)
In this study the L-W relationship parameters and condition factor for gender structure of the population of Salmo peristericus are given for the first time. The results of this study are aiming to provide information that can be of use for the conservation and management of the population of Salmo persitericus in Leva, Kranska and Brajčinska rivers on the territory of North Macedonia.

For assessment of individual health and trout habitat conditions inhabiting a stream or river, length and length regression calculations are frequently used [22, 23-29]. The mathematical relationship between the length and weight is one of the indicators of changes in the relation within different environmental conditions and stages of development, growth and maturity of fish $[30,31,32]$. The allometric growth formula to describe the weightlength relationship was originally proposed by [33, 34-38] indicate the influence on parameter $b$ and its variation by season, even daily and/or influenced by the number of samples examined, locality, habitat composition, degree of digestive tract filling, time of spawning (fullness of the gonads), sex and actual health status of the fish.

According to reference [39], as the length increases, the weight of the fish also increases logarithmically, with a value between 2.5 and 3.5 usually being 3.0. Values ranging from 2.5 to 4.0 according to reference [40] are considered ideal for fish. References [41, 42] report that the $b$ value is reaching up to 3.0, as well as the fact that quite a number of fish species are approaching that value. Reference [43] indicated differences in $b$ values due to factors affectting growth fish, such as water quality and nutrition supplemented habitat.

Kranska River female trout and Brajčinska River female and male coefficient $b$ indicates negative allometric population growth of Prespa trout, meaning that the trout becomes thinner with increasing length [44]. Concerning the male populartion from Kranska River has positive allometric relationship, indicating that trout weight increases along with its length increase.

Even though the condition factor is highly influenced by many parameters. It can be used as an indicator for habitat loss and/or habitat quality for threatened or endangered fish species [45, 46, 47]. Because the condition factor is based on the weight and length relationship, the assumption that the growth of length and weight is good, if the conditions of the nutrition environment and food availability is provided. 
It is known that the increasing of $\mathrm{pH}$ values in experimental conditions gave increased values on the Fulton's factor of the trout [48]. Having in mind that the measurements of the $\mathrm{pH}$ values of Kranska, Brajčinska and Leva rivers are neutral to slightly alkaline (Table 1), it is understandable that such a habitat is favorable for the Prespa trout.

Low condition factor is characterized in trout with smaller body size and early maturation, inhabiting small rivers, also existing in isolated populations [49]. The results of this study regarding the new research data that trout's low condition factor are in accordance with studies by [50-52], who also state the low condition factor as a characteristic for the smaller body size.

According to the standardized values of condition factor for salmonid fish, FCF value of 1 is a "poor fish", while fish with FCF value of 0.8 is "extremely poor fish" [20, 21]. Considering these standardized values, the Prespa trout in Brajčinska, Kranska and Leva rivers on average, is a fish with poor condition. Even more, the population of Salmo peristericus from Brajčinska and Leva rivers ranges from a "poor" to "extremely poor fish".

The condition factor in trout increases values in both sexes during the spawning season due to the increased weight of the gonads [53]. However, in this study males from the population of the Prespa trout have higher FCF, than the females, as analyzed in all three rivers. The growth in juveniles affects the condition factor as seen in the Atlantic salmon [54]. Therefore, it is possible that the low condition factor in juvenile Salmo peristericus is because they use their energy for growth instead for storage. Even though condition factor is a known indicator of nutritional condition, caution should be taken before drawing conclusions on the extremely poor and poor condition and future seasonal analysis should be performed in order to establish a baseline for FCF value of Salmo peristericus.

\section{CONCLUSION}

Results for the condition coefficient and lengthweight relationship indicate poor to extremely poor condition of Salmo pelistericus from the investigated Brajčinska, Kranska and Leva rivers watercourses. The examined trout was elongated, with a long slender body and low body weight value. In order to fully explain the low condition factor and the allometric growth of the Prespa trout, a further extended research analysis should be taken, concerning the food consumption, food composition parameters and food availability of the Prespa trout and its habitats.

Acknowledgements: This study was financed by Prespa Ohrid Nature Trust (PONT) and BirdLife International/Critical Ecosystems Partnership Fund (CEPF) under the project "Monitoring and conservation of the endemic and endangered Prespa trout (Salmo peristericus) in the National Park Pelister and Prespa Region" implemented by Balkan Foundation for Sustainable Development (BFSD). We thank Mr. Jonche Gagovski and Mr. Filip Gagovski for field guidance and assistance in the electrofishing during the sampling period. We also thank the anonymous reviewers whose comments improved the paper.

\section{REFERENCES}

[1] Crivelli, A. J., Koutseri, I., Petkovski, S. (2008): The Prespa trout, Salmo peristericus Karaman 1938, an endangered species in need of action, A Society of Prespa, BIOECO and Tour du Valat Publication, pp. 26.

[2] Smith, K. G., Darwall, W. R. T. (2006): The Status and Distribution of Freshwater Fish Endemic to the Mediterranean Basin, IUCN: Gland, Switzerland, Cambridge, UK, pp. $1-34$.

[3] Koutseri, I., Crivelli, A. J., Petkovski, S., Kazoglou, Y. (2010): Species action plan for the endemic Prespa trout, Salmo peristericus: a conservation tool, Proceedings of the Conference BALWOIS 2010, Ohrid, Republic of Macedonia, pp. 1-18.

[4] Spirkovski, Z., Kapedani, E., Pallugqi, A., Ilic-Boeva, D., Kostov, V., Taleski, T., Stojanovski, S., Beli, E,. Veljanoska-Sarafiloska, E., Stafilov, T., Bačeva, K., Kostoski G. (2012): Transboundary Fish and Fisheries Management Plan for Prespa Lakes Basin, Technical Report.

[5] Kostov, V. (2017): Research of the fishing fauna of the rivers: Patishka, Gradecka, Brajčinska and Stanišar on the part of the water intakes of the constructed Small Hydro Power Plants, Report for PCC Hidro DOOEL, owner of SHPP.

[6] Kostov, V., Ristovska, M., Manevska I. (2017): Research of the fishing fauna of the rivers: Kriva River, Krkljanska, Brbušnica, Kamenička, Brajčinska, Kranska and Selečka, on the part of the water intakes for the constructed Small Hydro Power Plants, Report for DTPU Small HYDRO PLANTS DOO Skopje.

[7] Berrebi, P., Tougard, C., Dubois, S., Shao, Z., Koutseri, I., Petkovski, S., Crivelli, A. (2013): Genetic diversity and conservation of the Prespa trout in the Balkans, International Journal of Molecular Sciences, Vol. 14, No. 12, pp. 23454-23470.

[8] Stevenson, R. D., Woods, Jr., W. A. (2006): Condition indices for conservation: new uses for evolving tools, Integrative and Comparative Biology, Vol. 46, No. 6, pp. 1169-1190.

[9] Stickney, R. R. (1972): Length-Weight Relationships for Several Fishes and Invertebrates in Georgia Coastal Waters with Condition Factors for Fish Species, University System of Georgia. 
[10] Petrakis, G., Stergiou, K. I. (1995): Weight-length relationships for 33 fish species in Greek waters, Fisheries Research, Vol. 21, No. 3-4, pp. 465-469.

[11] Dulčić, J., Kraljević, M. (1996): Weight-length relationships for 40 fish species in the eastern Adriatic (Croatian waters), Fisheries Research, Vol. 28, No. 3, pp. 243-251

[12] Le Cren, E. D. (1951): The length-weight relationship and seasonal cycle in gonad weight and condition in the perch (Perca fluviatilis), The Journal of Animal Ecology, pp. 201-219.

[13] Bagenal, T. B., Tesch, F. W. (1978): Methods for assessment of Fish Production in Fresh Waters, Age and Growth, Blackwell Science Publications, 3. ed.

[14] Sani, R., Gupta, B. K., Sarkar, U. K., Pandey, A., Dubey, V. K., Singh Lakra, W. (2010): Length-weight relationships of 14 Indian freshwater fish species from the Betwa (Yamuna River tributary) and Gomti (Ganga River tributary) rivers, Journal of Applied Ichthyology, Vol. 26, Iss. 3, pp. 456-459.

[15] Simon, K. D., Mazlan, A. G. (2008): Length-weight and length-length relationships of archer and puffer fish species, The Open Fish Science Journal,Vol. 1, No. 1, pp. 1922.

[16] Simon, K. D., Bakar, Y., Samat, A., Zaidi, C. C., Aziz, A., Mazlan, A. G. (2009): Population growth, trophic level, and reproductive biology of two congeneric archer fishes (Toxotes chatareus, Hamilton 1822 and Toxotes jaculatrix, Pallas 1767) inhabiting Malaysian coastal waters. Journal of Zhejiang University Science B, Vol. 10, No. 12, pp. 902911.

[17] Froese, R. (2006): Cube law, condition factor and weightlength relationships: history, meta-analysis and recommendations, Journal of Applied Ichthyology, Vol. 22, No. 4, pp. 241-253.

[18] Rounsefell, G. A., Everhart, W. H. (1953): Fishery Science: Its Methods and Applications, Wiley.

[19] Lagler, K. F. (1966): Freshwater Fishery Biology. Dubuque, IA, USA, WMC Brown Company.

[20] Fulton, T. W. (1904): The rate of growth of fishes, Fisheries Board of Scotland, Annual Report 22, Edinburgh (Part 3), pp. 141-241.

[21] Barnham, C., Baxter, A. (1998): Condition factor, K, for Salmonid Fish, Fisheries Notes, ISSN pp. 1440-2254.

[22] Reimers, N. (1963): Body condition, water temperature, and over-winter survival of hatchery-reared trout in Convict Creek, California, Transactions of the American Fisheries Society, Vol. 92, No. 1, pp. 39-46.

[23] Cada, G. F., Loar, J. M., Sale, M. J. (1987): Evidence of food limitation of rainbow and brown trout in southern Appalachian soft-water streams, Transactions of the American Fisheries Society, Vol. 116, No. 5, pp. 692-702.

[24] Murphy, K. D. (1988): Age and growth of wild rainbow trout, Salmogairdneri, in the Kings River, Fresno County, California. Humboldt State University, senior thesis.

[25] Anderson, R. O. (1990): Properties of relative weight and other condition indexes-comment, Transactions of the American Fisheries Society, Vol. 119, No. 6, pp. 1048 1058.

[26] Ensign, W. E., Strange, R. J., Moore, S. E. (1990): Summer food limitation reduces brook and rainbow trout biomass in a southern Appalachian stream. Transactions of the American Fisheries Society, Vol. 119, No. 5, pp. 894-901.

[27] Miranda, L. E., Jackson, D. C. (1990): Properties of relative weight and other condition indexes-comment, Transactions of the American Fisheries Society, Vol. 119, No. 6, pp. 1052-1052.

[28] Springer, T. A., Murphy, B. R. (1990): Properties of relative weight and other condition indices, Transactions of American Fisheries Society, Vol. 119, No. 6, pp. 10481058, DOI:10.1577/1548-8659-119.6.1048.

[29] Filbert, R. B., Hawkins, C. P. (1995): Variation in condition of rainbow trout in relation to food, temperature, and individual length in the Green River, Utah, Transactions of the American Fisheries Society, Vol. 124, No. 6, pp. 824835 .

[30] Thomas, J. Venus S., Kurup, B. M. (2003): Length-weight relationship of some deep-sea fish inhabiting the continental slope beyond $250 \mathrm{~m}$ depth along the West Coast of India, NAGA, WorldFish Center Quarterly, Vol. 26, No. 2, pp. 17-21.

[31] Sarkar, U. K., Deepak, P. K. Negi, R. S. (2008): Lengthweight relationship of clown knifefish Chitala chitala (Hamilton 1822) from the River Ganga basin, India, Journal of Applied Ichthyology, Vol. 25, No. 2, pp. 232-233.

[32] Mir, J. I., Sarkar, U. K., Dwivedi, A. K., Gusain, O. P., Pal, A., Jena, J. K. (2012): Pattern of intrabasin variation in condition factor, relative condition factor and form factor of an Indian major carp, Labeo rohita (Hamilton $\mathrm{Bu}-$ chanan, 1822) in the Ganges basin, India, European Journal of Biological Sciences, Vol. 4, pp. 126-135.

[33] Huxley, J. S. (1924): Constant differential growth-ratios and their significance, Nature, Vol. 114, No. 2877, pp. 895-896

[34] Qasim, S. Z.: An appraisal of the studies on maturation and spawning in marine teleosts from the Indian waters, Indian Journal of Fisheries, Vol. 20, No. 1, pp. 166-181.

[35] Bal, D. V., Rao, K. V. (1973): Marine Fisheries, Tata McGraw-Hill Publishing Company, New Delhi, pp. 5173, 1984.

[36] Goncalves, J. M., Bentes, S. L., Lino, P. G., Ribeiro, J., Canario, A. V. M, Erzini, K. (1997): Weight-length relationships for selected fish species of the small-scale demersal fisheries of the south and south-west coast of Portugal, Fisheries Research, Vol. 30, No. 3, pp. 253-257.

[37] Wooten, R. J. (1998): Ecology of the Teleost Fishes, Klumer Academic Publishers, Dordrecht, The Netherlands.

[38] Özaydın, O., Uçkun, D., Akalın, S., Leblebici, S., Tosunoğlu, Z. (2007): Length-weight relationships of fishes captured from Izmir Bay, Central Aegean Sea, Journal of Applied Ichthyology, Vol. 23, No. 6, pp. 695-696.

[39] Carlander, K. D. (1950): Growth rate studies of saugers, Stizostedion canadense canadense (Smith) and yellow perch, Perca flavescens (Mitchill) from Lake of the Woods, Minnesota. Transactions of the American Fisheries Society, Vol. 79, No. 1, pp. 30-42.

[40] Hile, R. (1936): Age and growth of the cisco, Leucichthus arbedi (Lesuer), in lakes of the northeastern highlands, Wisconsin, U.S. Bureau of Fisheries Bulletin, Vol. 19, pp. 211-317. 
[41] Beverton, R. J. H., Holt, S. H. (2012): On the Dynamics of Exploited Fish Populations, Springer Science \& Business Media, Vol. 11.

[42] Ricker, W. E. (1958): Handbook of Computations for Biological Statistics of Fish Populations. Bull. Fish. Res. Bd. Canada, Vol. 119, pp. 300.

[43] Sparre, R. (1989): What is the optimum interval class size for length-frequency analysis? Fishbyte, Vol. 7, No. 2, pp. $1-23$.

[44] King, R. P. (1996): Length-weight relationships of Nigerian coastal water fishes, Naga, the ICLARM.

[45] Meretsky, V. J., Wegner, D. L., Stevens, L. E. (2000): Balancing endangered species and ecosystems: a case study of adaptive management in Grand Canyon, Environmental Management, Vol. 25, No. 6.

[46] Ruiz-Campos, G., Gomez-Ramirez, J. (1991): Age and growth of San Pedro Mrtir Rainbow trout, Oncorhynchus mykiss nelsoni Evermann, from Arroyo San Rafael, Baja California, Mexico. Bishop, CA: Desert Fishes Council, pp. 141-161.

[47] Gómex, M. E. (1991): Estudio del español hablaado en Catamarca entre el siglo XVI y XIX, a través de la poesía oral recogida en el'Cancionero de Catamarca'por Juan Alfonso Carrizo en 1926, In: El Eespañol de América: actas del III congreso internacional de el Español en América: Valladolid, 3 a 9 de julio de 1989, Consejería de Cultura y Turismo, pp. 1483-1490.

[48] Simmons, K. R., Cieslewicz, P. G., Zajicek, K. (1996): Limestone treatment of Whetstone Brook, Massachusetts.
II. Changes in the brown trout (Salmo trutta) and brook trout (Salvelinus fontinalis) fishery. Restoration Ecology, Vol. 4, No. 3, pp. 273-283.

[49] Sandlund, O. T., Jonsson, B. (2016): Life history plasticity: migration ceased in response to environmental change? Ecology of Freshwater Fish, Vol. 25, No. 2, pp. 225-233.

[50] Nikolsky, G. V. (1969): Theory of Fish Population Dynamics as the Biological Background for Rational Exploitation and Management of Fishery Resources, Oliver \& Boyd, Edinburgh. Pp. 323, No. 4.

[51] Nevdal, G., Lerby, R., Mbller, D. (1981): Variation in growth rate and age at first maturation in rainbow trout, FiskDir. Skr. Ser. HauUnders., Vol. 17, pp. 71-78.

[52] Johnsson, J., Hjesj, J., Felaming, I. (2001): Behavioural and heart rate responses to predation risk in wild and domesticated Atlantic salmon, Canadian Journal of Fisheries and Aquatic Sciences, Vol. 58, No. 4, pp. 788-794.

[53] Isaac-Nahum, V. J., Vazzoler, A. E. A. de M. (1983): Biologia reproductive de Micropogoria sfurnieri (desmarest, 1823) (Teleostei, Sciaenidae). Fator de condicao como indicador do Periodo de desova. Boletim do Instituto Ocenogrefica, Sao Paulo, Vol. 32, No. 1, pp. 63-69.

[54] Caldarone, E. M., MacLean, S. A., Sharack, B. (2012): Evaluation of bioelectrical impedance analysis and Fulton's condition factor as nonlethal techniques for estimating short-term responses in postsmolt Atlantic salmon (Salmo salar) to food availability, Fishery Bulletin, Vol. 110, No. 2. 
